\title{
Multi-Scale Evaluation of the Interphase Zone between the Overlay and Concrete Substrate: Methods and Descriptors
}

\author{
Łukasz Sadowski \\ Faculty of Civil Engineering, Wroclaw University of Science and Technology, Wybrzeże Wyspianskiego 27, \\ 50-370 Wroclaw, Poland; lukasz.sadowski@pwr.edu.pl; Tel.: +48-71-320-3742
}

Academic Editor: Jorge de Brito

Received: 9 August 2017; Accepted: 28 August 2017; Published: 1 September 2017

\begin{abstract}
This article presents the problem of examining the interphase zone between the overlay and concrete substrate at different levels of observation. The possibility of applying available modern research methods in order to examine the interphase zone with regard to the level of observation is presented. These levels were defined in the paper. Examples of tests that show a possible approach to the examination of the interphase zone are also presented.
\end{abstract}

Keywords: civil engineering; repair; non-destructive testing; concrete; interfaces; interphases

\section{Introduction}

The durability of layered concrete elements, both newly executed elements and also surface corroded elements that were repaired by the application of repair concrete, is strongly dependent on an appropriate adhesion between layers [1-4]. This appropriate adhesion is defined in standard as the desired minimum value of interlayer adhesion [5].

Figure 1 shows the semantic and etymological context of the examination of the interphase zone based on [6].

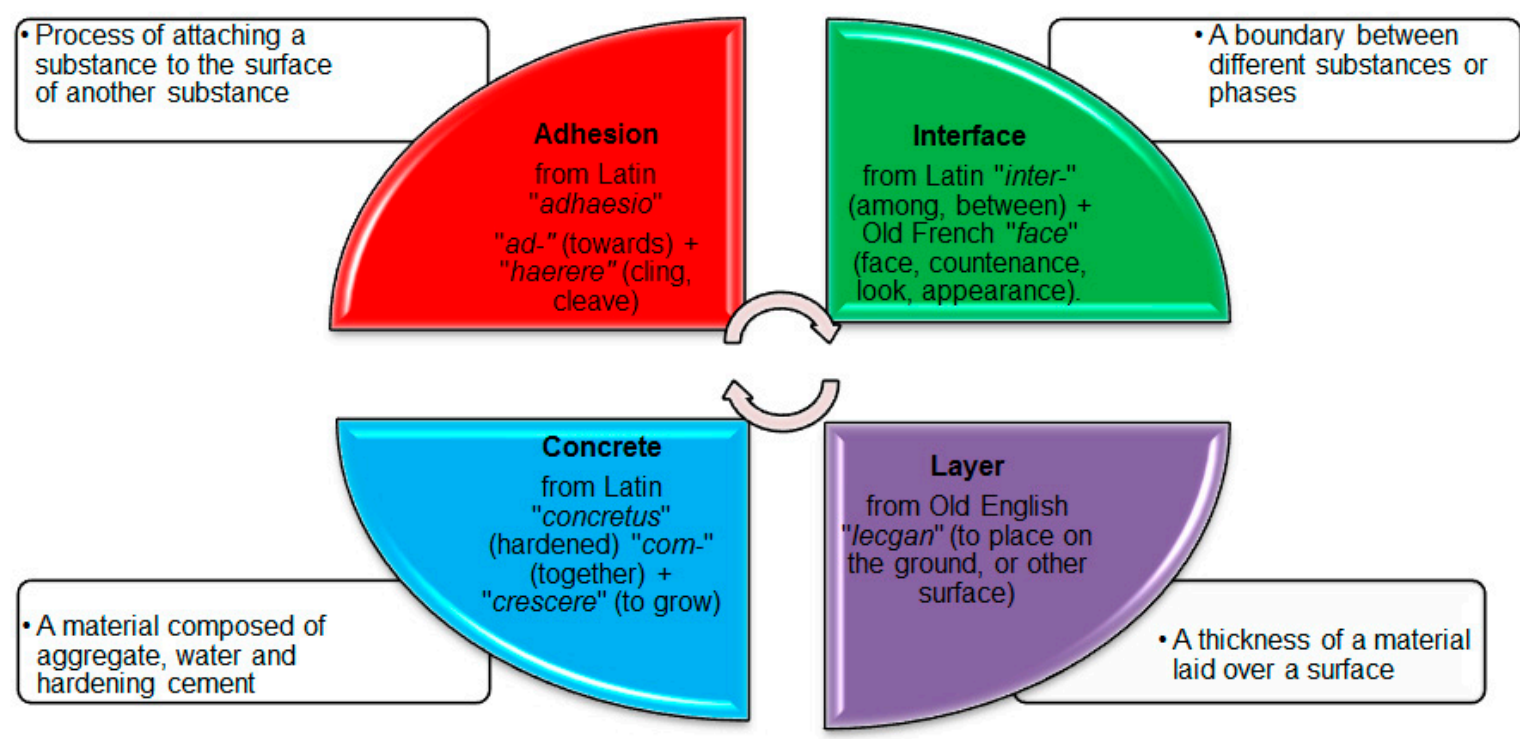

Figure 1. The semantic and etymological context of the evaluation of the bond between concrete layers (based on [6]). 
Therefore, this examination should be understood as an assessment of the phenomenon of the adhesion between two layers of a certain thickness made of a composite material that is composed of both aggregate and a liquid cement matrix that is hardening over time (Figure 1). Between the two materials, a thin layer or border in the form of an "interface" is created. However, according to [7], unlike the "interface" that is created after the application of the overlay onto an existing concrete substrate, it should be referred to as an "interphase" due to the maturation of overlay concrete.

In construction practice, the evaluation of the interphase zone between the overlay and a substrate is conducted macroscopically and is based on the evaluation of the pull-off adhesion value $\left(f_{\mathrm{b}}\right)$ using the destructive pull-off method [5]. The higher the $f_{\mathrm{b}}$ value, the better the bond is. Based on these tests, the "adhesion map" of the assessed surface of an element can be obtained, which can be used e.g., for the rough location of defective regions. Based on macroscopic examinations, it is also possible to assess whether the delamination occurred at the contact between layers (adhesion damage), or in the material of the overlay or substrate (cohesive damage), however, this does not explain why it happened. Recently, more and more different types of actions are being undertaken in order to increase the adhesion between layers to reach a value above the desired minimum value defined in the standard. These actions may include the following:

- appropriate treatment of the surface of the substrate, resulting in an increase in the effective relative surface area, orientation of the surface texture, removal of the cement laitance, surface exposure of the aggregate, etc.,

- increase the maximum aggregate grain size in concrete substrate,

- the applications of different adhesive substances,

- strengthening of the concrete substrate using impregnating and bonding agents,

- modification of the concrete composition, especially the overlay, with additives and nano-additives that "seal" its structure,

- modification of the concrete composition, especially the overlay, with admixtures that affect the viscosity of the concrete mix.

The examination of the interphase zone between layers at lower levels of observation could be helpful in these actions. This would require the use of modern testing methods other than the pull-off method. By knowing the distribution and structure of air pores in concrete in the interphase zone, it is possible to deliberately select an additive that will reduce porosity. In turn, knowledge of the chemical composition of the concrete in the interphase zone can help in the selection of a suitable bonding agent that is appropriate for increasing the adhesion in the interphase zone. Nowadays, "enhancement" of the adhesion is mainly performed experimentally and it involves samples of different microstructures being subjected to tests until there is one that has the desired parameters.

Taking the above into consideration, the purpose of this paper is to indicate the possibilities of using both available modern testing methods and descriptors that are assessed using these methods in order to evaluate the interphase zone between the overlay and concrete substrate at various levels of observation. Moreover, the paper defines these levels and indicates extensive literature, which includes, among others, examples of the author's own research.

\section{Literature Review}

Recently, the study of the interphase zone between the overlay and concrete substrate mainly consisted of macroscopic investigations using the previously mentioned "adhesion maps", which were created with the use of the pull-off method $[8,9]$ or by testing the interphase zone between large-scale concrete elements using bending [10,11], shear [12,13] and flexural strength [14-16]. Rough "adhesion maps" were also made based on results obtained using impact-echo and ultrasonic echo methods [17]. In turn, Sadowski and Hoła [18-24] proved that predicting the values of $f_{\mathrm{b}}$ is possible based on non-destructive testing (NDT) using artificial neural networks (ANN). 
An evaluation at a lower level of observation mainly involved the observation of the interphase zone and its destruction, which occurred after tests using the pull-off method [25-35] and also bending [36-40], shear [26,34,39,41-54], flexural [55,56], direct tensile [57,58], splitting prism [59], splitting tensile $[34,46,47,60-62]$ or bi-surface shear strength [63,64]. Although the sand patch test $[14,25]$ and the profilometric method $[44,65]$ are still popular for evaluating the surface morphology of concrete, Tayeh et al. [30], Siewczyńska [66], Hoła et al. [67] and Sadowski et al. [68] successfully used the 3D laser scanning method to evaluate the interphase zone between the overlay and concrete substrate. At the meso level, NDT involved the analysis of acoustic descriptors obtained with the use of the impact-echo method [69,70], the ultrasonic echo method [71,72], the ultrasonic pulse velocity method [73] and the acoustic emission method [74]. In literature, the infrared thermography method has been also used for the evaluation of the bond between overlay and concrete substrate [75].

In turn, micro-level studies were performed using a scanning electron microscopy $[36,47,57,76-78]$ and mercury intrusion porosimetry [57]. In recent years, it has been observed that X-ray micro-computed tomography $[79,80]$ and nanoindentation [81] are increasingly used to evaluate the interphase zone at micro and nano levels of observation. Czarnecki and Garbacz [82] and Pietrie [83] pointed out that the adhesion between concrete layers, as a multi-scale problem, should be investigated at different levels of observation.

\section{Levels of Examination of the Interphase Zone between the Overlay and Concrete Substrate}

On the basis of the literature review and the author's own experience, four levels of examination of the interphase zone between the overlay and concrete substrate were distinguished (Figure 2):

- 1st level (macro) - at this level, the interphase zone between layers is assessed primarily on the basis of destructive tests (or semi-nondestructive). Interlayer adhesion, which is useful, e.g., to create the so-called "adhesion maps", is then evaluated,

- 2nd level (meso) —at this level the interphase zone is evaluated on the basis of the physical and mechanical properties of the concrete of the substrate layer and the overlay, as well as on the basis of the surface morphology of the substrate layer,

- 3rd level (micro) - at this level the density, air pore structure and hardness of the concrete within the interphase zone are evaluated, as well as the changes of these properties over time,

- $\quad 4$ th level (nano) - at this level the interphase zone is evaluated by investigating the effects of valence intermolecular forces occurring between the contacting surfaces, and also the migration of elements from layer to layer at the atom, intermolecular level and molecular levels.

$\underline{1 \text { st level }}$

(macro)

2nd level

(meso)

\section{4th level}

(nano)

(micro) (nano)

\section{from $10^{0} \mathrm{~m}$ to $10^{-3} \mathrm{~m}$}

\section{from $10^{-3} \mathrm{~m}$ to $10^{-6} \mathrm{~m}$}

below $10^{-6} \mathrm{~m}$

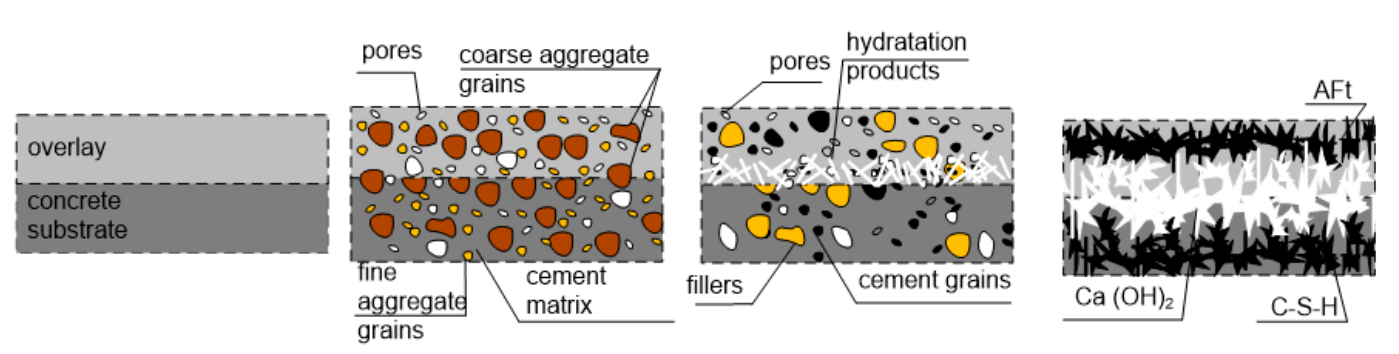

Figure 2. Four levels of examination (observation) of the interphase zone between the overlay and concrete substrate. 
Table 1 shows the results of a review of the available modern research methods, and also presents the basic descriptors that are evaluated in the interphase zone between the overlay and the concrete substrate using these methods. The table also indicates the suitability of these descriptors at a specified level of observation. In turn, Figure 3 presents data on the suitability of available modern research methods with regard to the level of observation of the interphase zone.

Table 1 and Figure 3 show that most of the examinations performed within the interphase zone were conducted at macro and meso levels using macroscopic methods (primarily the pull-off and shear method). With the development of modern research methods (especially scanning electron microscopy (SEM)), applications at the micro level were developed. According to the author, the interest in lower observation levels, with the use of nanoindentation and micro-computed tomography (micro-CT), is expected to increase.

Table 1. The suitability of the available research methods and the basic descriptors that were assessed to evaluate the interphase zone between an overlay and concrete substrate.

\begin{tabular}{|c|c|c|}
\hline Method Name & Basic Descriptors & Suitability \\
\hline Pull-off & $f_{\mathrm{b}}$-pull-off adhesion & 1,2 \\
\hline Bending & Crack propagation & 1,2 \\
\hline Shear & $\begin{array}{c}\text { Bond strength, } \\
\sigma_{\mathrm{n}} \text {-normal stress, } \\
\tau_{\mathrm{n}} \text {-shear stress, } \\
c-\text { cohesion coefficient }\end{array}$ & 1,2 \\
\hline Flexural & Bond strength & 1,2 \\
\hline $\begin{array}{l}\text { Direct tensile, } \\
\text { Splitting prism, } \\
\text { Bi-surface shear. }\end{array}$ & Bond strength & 2 \\
\hline Splitting tensile & $f_{\mathrm{t}}$-tensile strength of the interface & 2 \\
\hline Sand patch & SRI-Surface Roughness Index & 2 \\
\hline Profilometry & $\begin{array}{l}R_{\mathrm{p}} \text {-“peak-to-mean" roughness, } \\
R_{\mathrm{z}} \text {-mean peak-to-valley height }\end{array}$ & 2 \\
\hline 3D laser scanning & $\begin{array}{c}\text { Sku-kurtosis, } \\
\text { Str-texture aspect ratio, } \\
S b i \text {-surface bearing index, } \\
S c i-\text { core fluid rentention index, } \\
S v i \text { - valley fluid retention index, } \\
S a \text {-arithmetical mean height, } \\
S v \text {-maximum pit height, } \\
S p \text {-maximum peak height, } \\
S d r \text { - developed interfacial area ratio, } \\
S q \text {-root mean square height, } \\
\text { Ssk-skewness, } \\
V m p \text { - peak material volume }\end{array}$ & 1,2 \\
\hline Impulse response & $\begin{array}{c}K_{\mathrm{d}} \text { - } \text { dynamic stiffness, } \\
M_{\mathrm{p}} / N \text {-mobility slope, } \\
N_{\mathrm{av}} \text {-average mobility, } \\
v \text {-voids index }\end{array}$ & 1 \\
\hline Impact-echo & $\begin{array}{c}A \text {-amplitude of transmit dilatational stress wave, } \\
f \text {-the frequency of the dilatational stress wave }\end{array}$ & 1,2 \\
\hline Infrared thermography & $C_{\mathrm{T}}$-thermal contrast & 1,2 \\
\hline $\mathrm{UPV}^{1}$ & $t$ - time of the ultrasonic wave transiting & 2 \\
\hline $\mathrm{AE}^{2}$ & Crack propagation & 2 \\
\hline
\end{tabular}


Table 1. Cont.

\begin{tabular}{ccc}
\hline Method Name & Basic Descriptors & Suitability \\
\hline Optical microscopy & $A_{\mathrm{A}}$-exposed aggregate share & 2,3 \\
\hline X-ray micro-CT ${ }^{3}$ & $\mu$-attenuation coefficient & 3 \\
\hline Nanoindentation & $\begin{array}{c}H \text {-hardness, } \\
\text { SEM }\end{array}$ & 3 \\
\hline -indentation modulus & 3,4 \\
\hline
\end{tabular}

${ }^{1}$ ultrasonic pulse velocity (UPV), ${ }^{2}$ acoustic emission (AE), ${ }^{3}$ computed tomography (CT), ${ }^{4}$ scanning electron microscopy (SEM).

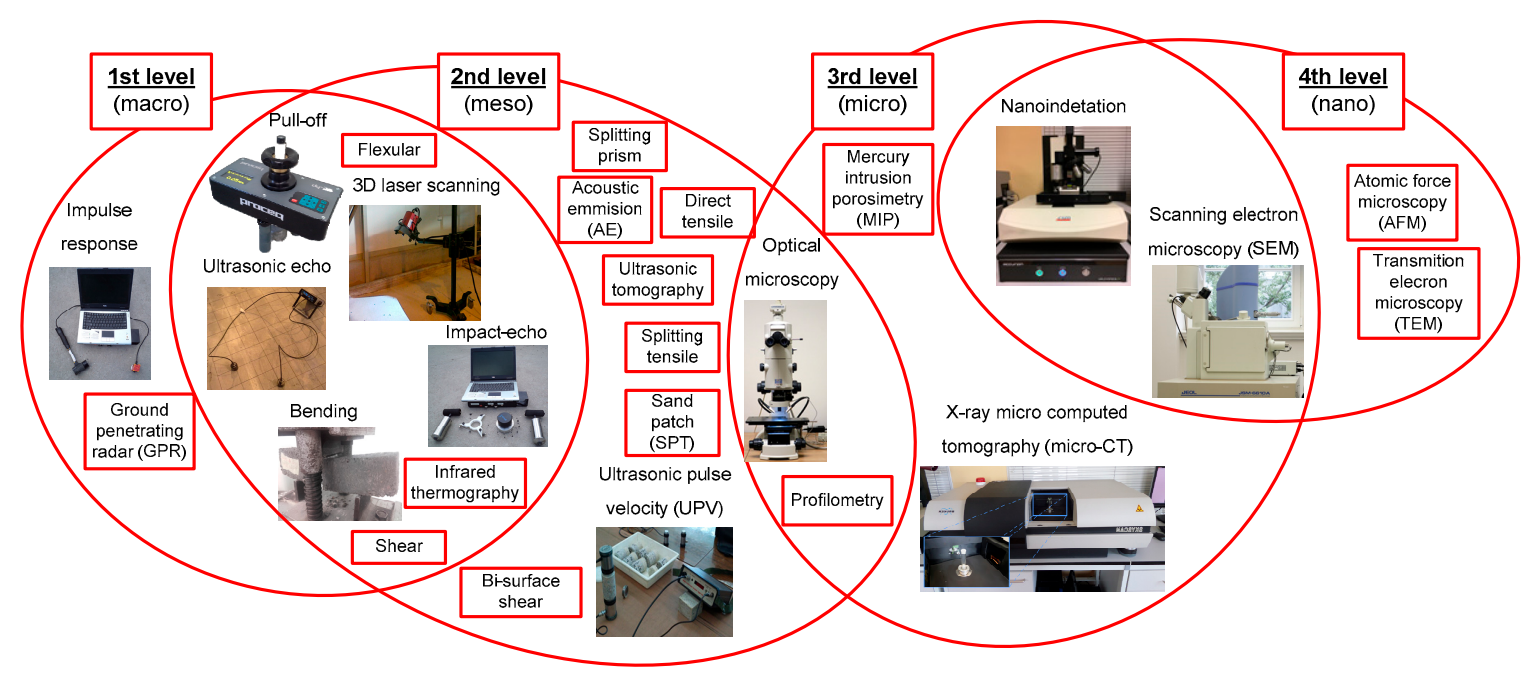

Figure 3. The suitability of the available modern research methods with regards to the level of examination (observation) of the interphase zone between the overlay and concrete substrate.

\section{The Proposed Methodology for the Evaluation of the Interphase Zone between the Overlay and Concrete Substrate}

Figure 4 presents the author's methodology of the evaluation of the interphase zone between the overlay and concrete substrate.

As can be seen from Figure 4, delaminations (non-destructive evaluation) can be sought for the 1 st level using NDT methods. The value of $f_{\mathrm{b}}$ can be obtained from tests either by using the destructive pull-off method or NDT methods and the ANN.

Based on the basis of investigating concrete surface morphology, which was specified in [4], 2nd level studies should aim to evaluate the surface morphology of the concrete substrate. Particular attention should be paid to the influence of the adhesion between layers on the maximum size of aggregate grains in the substrate concrete [67], the degree of the development of the substrate surface and the degree of exposing the aggregate on the surface of this layer caused by different methods of its preparation.

In turn, 3rd level investigations should aim to describe the course and structure of the air pores in the concrete of the interphase zone with regard to the method of preparing the surface of the substrate and the effect of this contribution on the adhesion of the layers. These tests can be performed using $\mathrm{X}$-ray computer microtomography. At this level of observation, the hardness of the concrete in the interphase zone can be assessed using the nanoindentation method.

At the 4th level of examination, the testing of concrete in the interphase zone between layers should be performed using the SEM. The analysis should include e.g., the examination of the chemical 
composition of concrete in the interphase zone and especially the percentage shares of elements and oxides as a function of the sample's thickness.

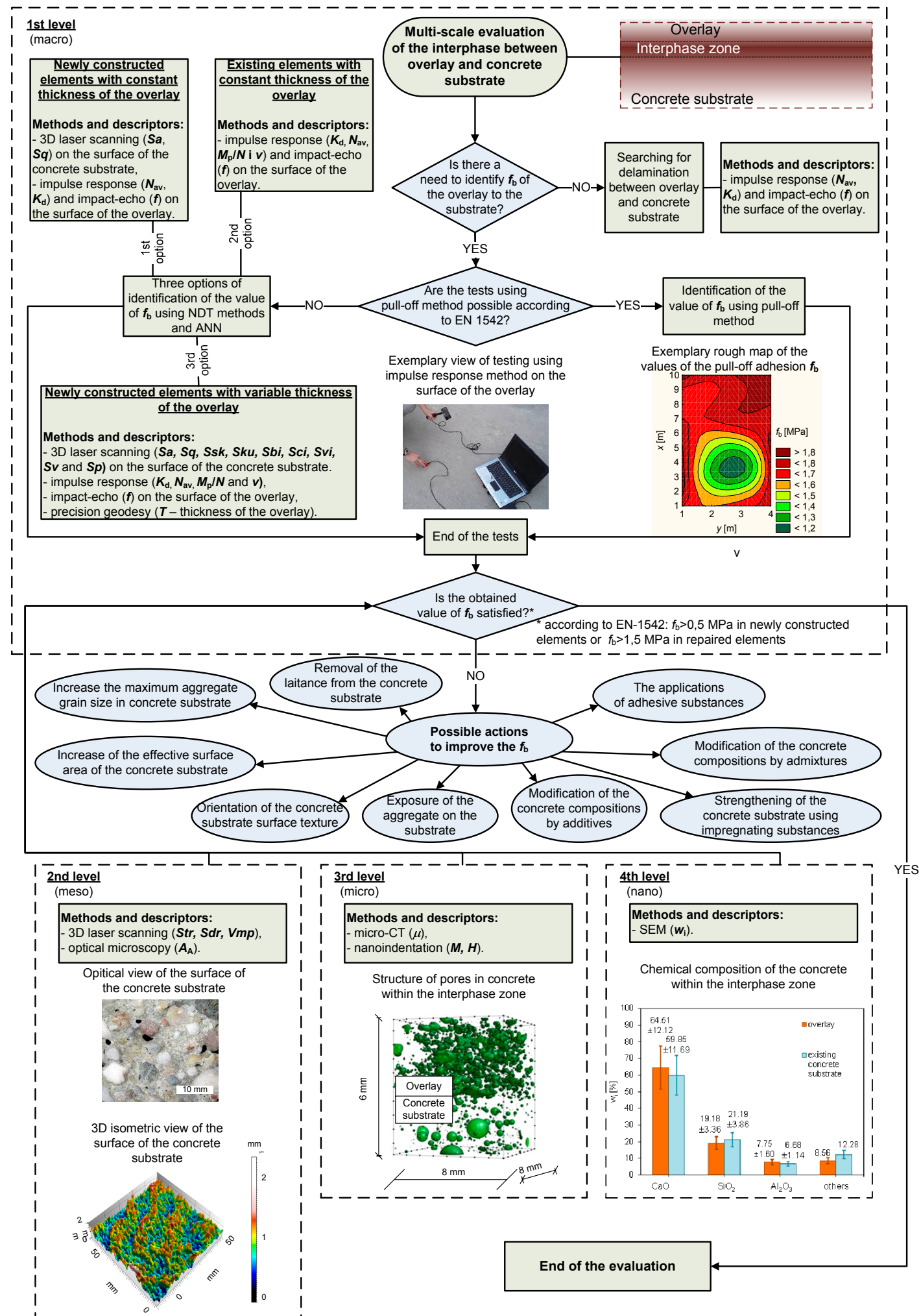

Figure 4. The proposed methodology of the evaluation of the interphase zone between the overlay and concrete substrate with regard to the level of observation. 


\section{Summary}

The actual problem of the examination of the interphase zone between the overlay and concrete substrate at different levels of observation has been presented in the article. Due to the high heterogeneity of joining materials, the multi-scale approach has been discussed. Four levels of examination (observation) of the interphase zone between the overlay and concrete substrate were distinguished based on the literature survey and the author's own experience:

- 1st level (macro) —at this level the interphase zone between layers is assessed primarily on the basis of destructive tests,

- 2nd level (meso) - at this level the interphase zone is evaluated on the basis of the physical and mechanical properties of the concrete of the substrate layer and the overlay, as well as on the basis of the surface morphology of the substrate,

- 3rd level (micro) - at this level the density, air pore structure and hardness of the concrete within the interphase zone are evaluated, as well as the changes of these properties over time,

- 4th level (nano) - at this level the interphase zone is evaluated by investigating the effects of valence intermolecular forces occurring between the contacting surfaces, and also the migration of elements from layer to layer at the atom, intermolecular level and molecular levels.

The possibility of using modern research methods and the basic descriptors evaluated using these methods were presented. Moreover, the suitability of these descriptors at a specific level of observation was indicated. Finally, the author's methodology of investigating the interphase zone between the overlay and concrete substrate with regard to the level of observation was also provided.

Today, the condition of the interphase zone between the overlay and concrete substrate can be increasingly and more precisely diagnosed. This is mainly due to the wide and continually extended range of methods useful for this purpose. In recent years, the research was primarily based on macroscopic laboratory testing methods. At the meso level, testing involves the use of the NDT acoustic and thermographic methods. In turn, micro-level studies were performed using a scanning electron microscopy and mercury intrusion porosimetry.

The anticipated development trends will likely be related to the applications of X-ray micro-CT and nanoindentation at nano level of observation. Especially with the proper combination of these methods, researchers will probably be able to observe the structure of pores and the density of the material at nano scale. Future work should also be related to the multi-scale optimization of the interphase zone between the overlay and concrete substrate. This can be done based on appropriate dosing of ingredients and proper method selection. The functional performance concrete concept (pointed out in [84]) can play a dominant role in the manufacturing of high quality multi-layer concrete elements.

Until now, a large development in the knowledge in the field of the interphase zone between the overlay and concrete substrate has been achieved. To continue building on this knowledge, further steps need to be taken. The evaluation of the interphase zone between the overlay and concrete substrate is an ongoing problem. It is a multi-phase combination of the physicochemical, mechanical and rheological properties of joined materials at different levels of observation. This is probably one of the most challenging aspects at the moment. Thus, the specific multi-scale processing algorithms and numerical methods need to be developed for this purpose.

Acknowledgments: This work was supported by the National Centre of Science, Poland under Grant number 2014/15/D/ST8/00550 ["Evaluation of the interlayer bond of variably thick concrete layers based on nondestructive tests using artificial intelligence"].

Conflicts of Interest: The author declares no conflict of interest. The founding sponsors had no role in the design of the study; in the collection, analyses, or interpretation of data; in the writing of the manuscript, and in the decision to publish the results. 


\section{References}

1. Czarnecki, L.; Łukowski, P.; Garbacz, A. The Protection and Repair of Concrete Structures; Comment to PN-EN 1504; PWN: Warsaw, Poland, 2016. (In Polish)

2. Safiuddin, M. Concrete Damage in Field Conditions and Protective Sealer and Coating Systems. Coatings 2017, 7, 90. [CrossRef]

3. Czarnecki, L.; Chmielewska, B. Factors affecting the adhesion in building joints. Cem. Lime Concr. 2005, 10, 74-85.

4. Sadowski, Ł.; Mathia, T.G. Multi-scale metrology of concrete surface morphology: Fundamentals and specificity. Constr. Build. Mater. 2016, 113, 613-621. [CrossRef]

5. EN 1542:2000. Products and Systems for the Protection and Repair of Concrete Structures. Test Methods. Measurements of Bond Strength by Pull-Off; European Committee for Standardization: Belgium, Brussels, 2000.

6. Douglas, H. Online Etymology Dictionary. 2007. Available online: http://www.etymonline.com/index.php (accessed on 20 August 2017).

7. Bissonnette, B.; Courard, L.; Garbacz, A. Concrete Surface Engineering; CRC Press: Boca Raton, FL, USA, 2015.

8. Girhammar, U.A.; Pajari, M. Tests and analysis on shear strength of composite slabs of hollow core units and concrete topping. Constr. Build. Mater. 2008, 22, 1708-1722. [CrossRef]

9. Adawi, A.; Youssef, M.A.; Meshaly, M.E. Experimental investigation of the composite action between hollowcore slabs with machine-cast finish and concrete topping. Eng. Struct. 2015, 91, 1-15. [CrossRef]

10. Halicka, A. Influence new-to-old concrete interface qualities on the behaviour of support zones of composite concrete beams. Constr. Build. Mater. 2011, 25, 4072-4078. [CrossRef]

11. Mansour, F.R.; Bakar, S.A.; Vafaei, M.; Alih, S.C. Effect of substrate surface roughness on the flexural performance of concrete slabs strengthened with a steel-fiber-reinforced concrete layer. PCI J. 2017, 62, 78-89.

12. Niwa, J.; Matsumoto, K.; Sato, Y.; Yamada, M.; Yamauchi, T. Experimental study on shear behavior of the interface between old and new deck slabs. Eng. Struct. 2016, 126, 278-291. [CrossRef]

13. Cavaco, E.; Camara, J. Experimental research on the behaviour of concrete-to-concrete interfaces subjected to a combination of shear and bending moment. Eng. Struct. 2017, 132, 278-287. [CrossRef]

14. Fernandes, H.; Lúcio, V.; Ramos, A. Strengthening of RC slabs with reinforced concrete overlay on the tensile face. Eng. Struct. 2017, 132, 540-550. [CrossRef]

15. Mansour, F.R.; Bakar, S.A.; Ibrahim, I.S.; Marsono, A.K.; Marabi, B. Flexural performance of a precast concrete slab with steel fiber concrete topping. Constr. Build. Mater. 2015, 75, 112-120. [CrossRef]

16. Perez, F.; Bissonnette, B.; Gagné, R. Parameters affecting the debonding risk of bonded overlays used on reinforced concrete slab subjected to flexural loading. Mater. Struct. 2009, 42, 645-662. [CrossRef]

17. Czarnecki, L.; Garbacz, A.; Krystosiak, M. On the ultrasonic assessment of adhesion between polymer coating and concrete substrate. Cem. Concr. Compos. 2006, 28, 360-369. [CrossRef]

18. Sadowski, Ł.; Hoła, J. ANN modeling of pull-off adhesion of concrete layers. Adv. Eng. Softw. 2015, 89, 17-27. [CrossRef]

19. Sadowski, Ł.; Hoła, J.; Czarnecki, S. Non-destructive neural identification of the bond between concrete layers in existing elements. Constr. Build. Mater. 2016, 127, 49-58. [CrossRef]

20. Sadowski, Ł.; Nikoo, M.; Nikoo, M. Hybrid Metaheuristic-Neural Assessment of the Adhesion in Existing Cement Composites. Coatings 2017, 7, 1-12. [CrossRef]

21. Sadowski, Ł.; Nikoo, M.; Nikoo, M. Principal Component Analysis combined with a Self Organization Feature Map to determine the pull-off adhesion between concrete layers. Constr. Build. Mater. 2015, 78, 386-396. [CrossRef]

22. Sadowski, Ł.; Hoła, J.; Czarnecki, S.; Wang, D. Pull-off adhesion value prediction of variable thick overlay to the substrate. Autom. Constr. 2017. under review.

23. Sadowski, Ł. Non-destructive identification of pull-off adhesion between concrete layers. Autom. Constr. 2015, 57, 146-155. [CrossRef]

24. Sadowski, Ł.; Hoła, J. New nondestructive way of identifying the values of pull-off adhesion between concrete layers in floors. J. Civ. Eng. Manag. 2014, 20, 561-569. [CrossRef]

25. Courard, L.; Piotrowski, T.; Garbacz, A. Near-to-surface properties affecting bond strength in concrete repair. Cem. Concr. Compos. 2014, 46, 73-80. [CrossRef] 
26. Roy, M.; Ray, I.; Davalos, J.F. High-performance fiber-reinforced concrete: Development and evaluation as a repairing material. J. Mater. Civ. Eng. 2013, 26, 04014074. [CrossRef]

27. Huang, H.; Liu, B.; Xi, K.; Wu, T. Interfacial tensile bond behavior of permeable polymer mortar to concrete. Constr. Build. Mater. 2016, 121, 210-221. [CrossRef]

28. Naderi, M. Adhesion of different concrete repair systems exposed to different environments. J. Adhes. 2008, 84, 78-104. [CrossRef]

29. Mauroux, T.; Turcry, P.; Benboudjema, F.; Ait-Mokhtar, A. Influence of the time of demoulding on adhesion of cement-based mortar modified with cellulose ether. Eur. J. Environ. Civ. Eng. 2014, 18, 1157-1166. [CrossRef]

30. Tayeh, B.A.; Bakar, B.A.; Johari, M.M.; Ratnam, M.M. The relationship between substrate roughness parameters and bond strength of ultra high-performance fiber concrete. J. Adhes. Sci. Technol. 2013, 27, 1790-1810. [CrossRef]

31. Horszczaruk, E.; Brzozowski, P. Bond strength of underwater repair concretes under hydrostatic pressure. Constr. Build. Mater. 2014, 72, 167-173. [CrossRef]

32. Cleland, D.J.; Basheer, L. Pull-off adhesion testing for concrete repairs. Mag. Concr. Res. 2007, 59, 771-776. [CrossRef]

33. Skominas, R.; Gurskis, V.; Sadzevicius, R.; Damulevicius, V.; Radzevicius, A. Evaluation of cement mortar suitability for repairing concrete in hydraulic structures. KSCE J. Civ. Eng. 2017, 1-7. [CrossRef]

34. Harris, D.K.; Muñoz, M.A.C.; Gheitasi, A.; Ahlborn, T.M.; Rush, S.V. The challenges related to interface bond characterization of ultra-high-performance concrete with implications for bridge rehabilitation practices. Adv. Civ. Eng. Mater. 2014, 4, 75-101. [CrossRef]

35. Stolz, C.M.; Masuero, A.B.; Pagnussat, D.T.; Kirchheim, A.P. Influence of substrate texture on the tensile and shear bond strength of rendering mortars. Constr. Build. Mater. 2016, 128, 298-307. [CrossRef]

36. Mallat, A.; Alliche, A. Mechanical investigation of two fiber-reinforced repair mortars and the repaired system. Constr. Build. Mater. 2011, 25, 1587-1595. [CrossRef]

37. Lanzoni, L.; Soragni, M.; Tarantino, A.M.; Viviani, M. Concrete beams stiffened by polymer-based mortar layers: Experimental investigation and modeling. Constr. Build. Mater. 2016, 105, 321-335. [CrossRef]

38. Tsioulou, O.T.; Lampropoulos, A.P.; Dritsos, S.E. Experimental investigation of interface behaviour of RC beams strengthened with concrete layers. Constr. Build. Mater. 2013, 40, 50-59. [CrossRef]

39. Zhang, D.; Ueda, T.; Furuuchi, H. Fracture mechanisms of polymer cement mortar: Concrete interfaces. J. Eng. Mech. 2012, 139, 167-176. [CrossRef]

40. Minafò, G. A practical approach for the strength evaluation of RC columns reinforced with RC jackets. Eng. Struct. 2015, 85, 162-169. [CrossRef]

41. Saldanha, R.; Júlio, E.; Dias-da-Costa, D.; Santos, P. A modified slant shear test designed to enforce adhesive failure. Constr. Build. Mater. 2013, 41, 673-680. [CrossRef]

42. Zanotti, C.; Banthia, N.; Plizzari, G. A study of some factors affecting bond in cementitious fiber reinforced repairs. Cem. Concr. Res. 2014, 63, 117-126. [CrossRef]

43. Santos, P.M.; Julio, E.N. Correlation between concrete-to-concrete bond strength and the roughness of the substrate surface. Constr. Build. Mater. 2007, 21, 1688-1695. [CrossRef]

44. Santos, P.M.D.; Júlio, E.N.B.S. Development of a laser roughness analyser to predict in situ the bond strength of concrete-to-concrete interfaces. Mag. Concr. Res. 2008, 60, 329-338. [CrossRef]

45. Tayeh, B.A.; Abu Bakar, B.H.; Megat Johari, M.A.; Ratnam, M.M. Existing concrete textures: Their effect on adhesion with fibre concrete overlay. Proc. Inst. Civ. Eng. Struct. Build. 2014, 167, 355-368. [CrossRef]

46. Tayeh, B.A.; Bakar, B.A.; Johari, M.M. Characterization of the interfacial bond between old concrete substrate and ultra high performance fiber concrete repair composite. Mater. Struct. 2013, 46, 743-753. [CrossRef]

47. Tayeh, B.A.; Bakar, B.A.; Johari, M.M.; Voo, Y.L. Mechanical and permeability properties of the interface between normal concrete substrate and ultra high performance fiber concrete overlay. Constr. Build. Mater. 2012, 36, 538-548. [CrossRef]

48. Lee, M.G.; Wang, Y.C.; Chiu, C.T. A preliminary study of reactive powder concrete as a new repair material. Constr. Build. Mater. 2007, 21, 182-189. [CrossRef]

49. Al-Osta, M.A.; Isa, M.N.; Baluch, M.H.; Rahman, M.K. Flexural behavior of reinforced concrete beams strengthened with ultra-high performance fiber reinforced concrete. Constr. Build. Mater. 2017, 134, 279-296. [CrossRef]

50. Diab, A.M.; Elmoaty, A.E.M.A.; Eldin, M.R.T. Slant shear bond strength between self compacting concrete and old concrete. Constr. Build. Mater. 2017, 130, 73-82. [CrossRef] 
51. Mirmoghtadaei, R.; Mohammadi, M.; Samani, N.A.; Mousavi, S. The impact of surface preparation on the bond strength of repaired concrete by metakaolin containing concrete. Constr. Build. Mater. 2015, 80, 76-83. [CrossRef]

52. Mohammadi, M.; Moghtadaei, R.M.; Samani, N.A. Influence of silica fume and metakaolin with two different types of interfacial adhesives on the bond strength of repaired concrete. Constr. Build. Mater. 2014, 51, 141-150. [CrossRef]

53. Hussein, H.H.; Walsh, K.K.; Sargand, S.M.; Steinberg, E.P. Interfacial properties of ultrahigh-performance concrete and high-strength concrete bridge connections. J. Mater. Civ. Eng. 2016, 28, 04015208. [CrossRef]

54. Beushausen, H.; Alexander, M.G. Bond strength development between concretes of different ages. Mag. Concr. Res. 2008, 60, 65-74. [CrossRef]

55. Belaidi, A.S.E.; Benabed, B.; Soualhi, H. Physical and mechanical properties of concrete repair materials in dry and hot-dry environment. J. Adhes. Sci. Technol. 2015, 29, 543-554. [CrossRef]

56. Aykac, S.; Kalkan, I.; Tankut, T. Flexural strengthening and repair of RC slabs by adding a new RC layer. Struct. Concr. 2016, 17, 896-909. [CrossRef]

57. Zhou, J.; Ye, G.; van Breugel, K. Cement hydration and microstructure in concrete repairs with cementitious repair materials. Constr. Build. Mater. 2016, 112, 765-772. [CrossRef]

58. Lampropoulos, A.P.; Paschalis, S.A.; Tsioulou, O.T.; Dritsos, S.E. Strengthening of reinforced concrete beams using ultra high performance fibre reinforced concrete (UHPFRC). Eng. Struct. 2016, 106, 370-384. [CrossRef]

59. Qian, Y.; Zhang, D.; Ueda, T. Interfacial Tensile Bond between Substrate Concrete and Repairing Mortar under Freeze-Thaw Cycles. J. Adv. Concr. Technol. 2016, 14, 421-432. [CrossRef]

60. Espeche, A.D.; León, J. Estimation of bond strength envelopes for old-to-new concrete interfaces based on a cylinder splitting test. Constr. Build. Mater. 2011, 25, 1222-1235. [CrossRef]

61. Zhang, J.; Ding, X.; Zhao, Q. Experimental and numerical investigation of scattering gravels on the surface bond strength of self-compacting concrete. Constr. Build. Mater. 2017, 145, 11-19. [CrossRef]

62. Carbonell Muñoz, M.A.; Harris, D.K.; Ahlborn, T.M.; Froster, D.C. Bond performance between ultrahigh-performance concrete and normal-strength concrete. J. Mater. Civ. Eng. 2013, 26, 04014031. [CrossRef]

63. Widodo, S. Bond Strength between Hybrid Fiber Reinforced Lightweight Aggregate Concrete Substrate and Self-Compacting Concrete as Topping Layer. Adv. Civ. Eng. 2017, 2017. [CrossRef]

64. Santos, D.S.; Santos, P.M.; Dias-da-Costa, D. Effect of surface preparation and bonding agent on the concrete-to-concrete interface strength. Constr. Build. Mater. 2012, 37, 102-110. [CrossRef]

65. Mohamad, M.E.; Ibrahim, I.S.; Abdullah, R.; Rahman, A.A.; Kueh, A.B.H.; Usman, J. Friction and cohesion coefficients of composite concrete-to-concrete bond. Cem. Concr. Compos. 2015, 56, 1-14. [CrossRef]

66. Siewczyńska, M. Method for determining the parameters of surface roughness by usage of a 3D scanner. Arch. Civ. Mech. Eng. 2012, 12, s83-s89. [CrossRef]

67. Hoła, J.; Sadowski, Ł.; Reiner, J.; Stach, S. Usefulness of 3D surface roughness parameters for nondestructive evaluation of pull-off adhesion of concrete layers. Constr. Build. Mater. 2015, 84, 111-120. [CrossRef]

68. Sadowski, Ł.; Czarnecki, S.; Hoła, J. Evaluation of the morphology of concrete substrate and their adhesion to epoxy resin. Int. J. Adhes. Adhes. 2016, 67, 3-13. [CrossRef]

69. Garbacz, A. Application of stress based NDT methods for concrete repair bond quality control. Bull. Polish Acad. Sci. Tech. Sci. 2015, 63, s77-s85. [CrossRef]

70. Garbacz, A.; Piotrowski, T.; Courard, L.; Kwaśniewski, L. On the evaluation of interface quality in concrete repair system by means of impact-echo signal analysis. Constr. Build. Mater. 2017, 134, 311-323. [CrossRef]

71. Garbacz, A. Non-Destructive Testing of Concrete-Like Polymeric Composites Using Elastic Waves-Evaluation of Repair Efficiency; Publishing House of Warsaw University of Technology: Warsaw, Poland, 2007; p. 208.

72. Tsioulou, O.; Lampropoulos, A.; Paschalis, S. Combined Non-Destructive Testing (NDT) method for the evaluation of the mechanical characteristics of Ultra High Performance Fibre Reinforced Concrete (UHPFRC). Constr. Build. Mater. 2017, 131, 66-77. [CrossRef]

73. Szymanowski, J.; Sadowski, Ł. Adhesion Assessment between Concrete Layers Using the Ultrasonic Pulse Velocity Method. Appl. Mech. Mater. 2015, 797, 145-150. [CrossRef]

74. Prem, P.R.; Murthy, A.R. Acoustic emission and flexural behaviour of RC beams strengthened with UHPC overlay. Constr. Build. Mater. 2016, 123, 481-492. [CrossRef] 
75. Iowa Department of Transportation, Donohue \& Associates, Inc. Engineers \& Architects. Evaluation of Bond Retainage in Portland Cement Concrete Overlays by Infrared Thermography and Ground Penetrating Radar, HR-537, 1988; Iowa Department of Transportation, Donohue \& Associates, Inc.: Fort Wayne, IN, USA, 1988.

76. Beushausen, H.; Höhlig, B.; Talotti, M. The influence of substrate moisture preparation on bond strength of concrete overlays and the microstructure of the OTZ. Cem. Concr. Res. 2017, 92, 84-91. [CrossRef]

77. Tayeh, B.A.; Abu Bakar, B.H.; Megat Johari, M.A.; Zeyad, A.M. Microstructural analysis of the adhesion mechanism between old concrete substrate and UHPFC. J. Adhes. Sci. Technol. 2014, 28, 1846-1864. [CrossRef]

78. Satoh, A.; Yamada, K. FEM simulation of tension struts on adhesion performance of mortar-repair interface. Eng. Fract. Mech. 2016, 167, 84-100. [CrossRef]

79. Lukovic, M.; Ye, G. Effect of moisture exchange on interface formation in the repair system studied by X-ray absorption. Materials 2015, 9. [CrossRef] [PubMed]

80. Sadowski, Ł.; Stefaniuk, D. Microstructural Evolution within the Interphase between Hardening Overlay and Existing Concrete Substrates. Appl. Sci. 2017, 7. [CrossRef]

81. Luković, M.; Šavija, B.; Dong, H.; Schlangen, E.; Ye, G. Micromechanical study of the interface properties in concrete repair systems. J. Adv. Concr. Technol. 2014, 12, 320-339. [CrossRef]

82. Czarnecki, L.; Garbacz, A. Adhesion of Interfaces of Building Materials: A Multi-Scale Approach. Advances in Materials Science and Restoration; Aedificatio Publishers: Freiburg im Breisgau, Germany, 2007; p. 260.

83. Petrie, E.M. Handbook of Adhesives and Sealants; McGraw-Hill: New York, NY, USA, 2000; p. 765.

84. Sadowski, Ł.; Popek, M.; Czarnecki, S.; Mathia, T.G. Morphogenesis in solidification phases of lightweight concrete surface at early ages. Constr. Build. Mater. 2017, 148, 96-103. [CrossRef]

(C) 2017 by the author. Licensee MDPI, Basel, Switzerland. This article is an open access article distributed under the terms and conditions of the Creative Commons Attribution (CC BY) license (http:// creativecommons.org/licenses/by/4.0/). 